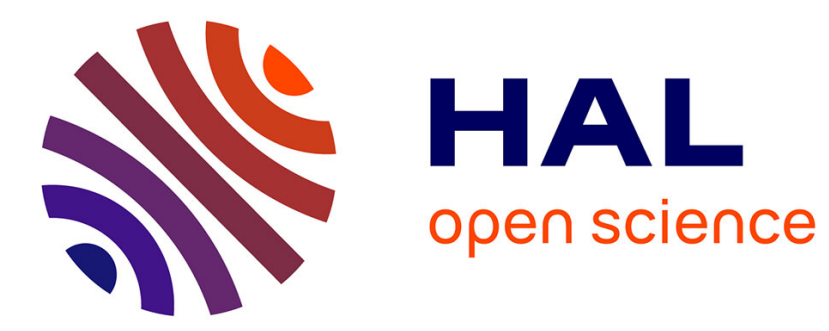

\title{
Sex Difference in Medieval Theology and Canon Law. A Tribute to Joan Cadden
}

Maaike van Der Lugt

\section{To cite this version:}

Maaike van Der Lugt. Sex Difference in Medieval Theology and Canon Law. A Tribute to Joan Cadden . Medieval Feminist Forum, 2010, 46 (1), pp.101-121. halshs-00546551

\section{HAL Id: halshs-00546551 https://shs.hal.science/halshs-00546551}

Submitted on 14 Dec 2010

HAL is a multi-disciplinary open access archive for the deposit and dissemination of scientific research documents, whether they are published or not. The documents may come from teaching and research institutions in France or abroad, or from public or private research centers.
L'archive ouverte pluridisciplinaire HAL, est destinée au dépôt et à la diffusion de documents scientifiques de niveau recherche, publiés ou non, émanant des établissements d'enseignement et de recherche français ou étrangers, des laboratoires publics ou privés. 


\section{Sex Difference in Medieval Theology and Canon Law: A Tribute to Joan Cadden}

Maaike van der Lugt

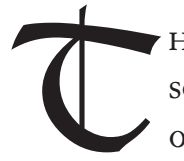

HE laudatio is a tricky genre, especially when addressed to someone of both such unfeigned modesty and sharp awareness of literary conventions as Joan Cadden. How, then, to express one's appreciation and admiration? Will it embarrass Joan to read that she is one of the most inspiring and intelligent, and one of the friendliest, most helpful, and generous scholars I know? (I hope it won't.) And, more important, will she believe me? (I hope she will.)

I should like to salute Joan here, especially, as a pioneer: as a female academic who made her way in a world that was, at the time far more so than today, dominated by men, and as the author of a highly innovative and thought-provoking book. Joan Cadden is one of the first historians who applied the question of the natural characteristics of men and women and the construction of gender to medieval debates about physiology, procreation, intercourse, and pleasure. In the early i980s, when she started the research which led up to Meanings of Sex Difference, these were groundbreaking questions. Even more important, Joan Cadden treated them in exemplary fashion, always careful to steer clear of anachronism, and with a keen eye for the complexities and ambiguities of the meanings she so patiently extracted from medieval texts.

Meanings of Sex Difference draws on a very wide range of sources, crossing and re-crossing traditional boundaries between the disciplines. Joan Cadden also pays particular attention to the cultural and social milieux these sources were produced in; to the assumptions and expectations of authors and readers; to questions of form, style, and presentation. ${ }^{\mathrm{I}}$ Today, it may be easy to forget that this approach to the history of science was, at the time, still very novel. For Joan Cadden herself, it constituted a sharp methodological break with respect to the tradition in which she had been trained. 
An important part of the interest of Meanings lies in Cadden's efforts to confront the outlook of learned physicians and natural philosophers on sex difference with the values of the Church and the views held in lay society at large. In doing so, Cadden is, moreover, attentive to differences in "level": it can be quite another thing to proclaim general principles than to take positions on specific issues. For instance, in general terms, Christian doctrine and medical opinion considered the chastity of men and women similarly, "religion tending to promote, and medicine tending to oppose strict sexual restraint as an ideal." However, in more specific discussions, "ecclesiastical and medical views converged with lay opinion, which placed significantly higher value upon female virginity, abstinence, chastity, and fidelity." ${ }^{2}$

The distinctions between "science," "the Church," and "lay society," understood as "different intellectual frameworks," are very helpful to capture the complexity and multilayeredness of medieval opinion about the gender implications of sex difference. Like all categories, they are, however, not entirely unproblematic. The distinction between science and the Church (or religion), in particular, may not always do full justice to the cross-disciplinary nature of scholastic thought itself.

In the medieval debate about sex difference, the Church cannot be understood only as a source of values and norms, as an institution that defined and enforced a sexual code. Medieval theologians and canonists also participated actively in contemporary learned discussions about the natural body. They did so, of course, as authors of technical works on natural philosophy; Albertus Magnus and Giles of Rome, who wrote highly influential treatises on zoology and embryology, are important cases in point. However, they did so also-as recent research by Caroline Bynum, Peter Biller, Alain Boureau, Joseph Ziegler, and others has brought to light-in strictly theological works. ${ }^{3}$ In discussions about the state of humanity before the fall, the resurrection at the end of time, the transmission of original sin, or the virgin birth, among other examples, scholastic theologians routinely made use of newly translated philosophical and medical learning. In some cases, theological discussions about physiology and the natural body are subtler and more original than those of the physicians and philosophers themselves. ${ }^{4}$

If we are to look for "new" - or at least "more"-meanings of sex 
difference, scholastic theology and canon law may be one of the places to turn to. As a brief continuatio to Meanings of Sex Difference, I shall chart two doctrinal debates, which Joan Cadden studies more incidentally and from a somewhat different angle.

The first of these debates concerns the general and fundamental question of the origin and raison d'être of sex difference: how and why did God create male and female bodies; or, as the issue is, revealingly, frequently understood, for what reason, and in which manner, did he create woman?5

One of the important points made by Cadden in her analysis of the medieval interpretation of Genesis is that the Bible and Aristotelian natural philosophy converged, despite crucial differences - most prominently Aristotle's belief in the beginninglessness and eternity of the world-on the idea of the purposefulness and perfection of the natural world. ${ }^{6}$ We shall see that scholastic theologians integrated Aristotelian notions of perfection and final causes into their accounts of the creation and actively discussed their accuracy, relevancy, and compatibility with the Christian outlook. One of my key sources is the treatise On the Human Body, which was probably written in the late 1250 os by an anonymous Franciscan and quickly appended to Alexander of Hales's monumental theological Summa. Roughly based on Genesis, On the Human Body is above all an anthropological treatise, similar, in some respects, to Augustine's highly influential De genesi ad litteram. It contains an exceptionally long chapter about the body of the first woman, which later found its way, albeit in much abbreviated form, into Thomas Aquinas's Summa. ${ }^{7}$

The confrontation with natural philosophy was, of course, only one of the influences that shaped scholastic views on sex difference. We shall see that more internal factors, such as the apparent contradictions within Genesis itself, the Augustinian heritage, and the need to take positions with respect to Greek and Jewish interpretations, as well as contemporary heresies, also explain how and why scholastics came to defend a relatively moderate view on the origin of woman, sex difference, and gender distinctions.

The second, more specific, yet partly intersecting debate I shall be examining concerns the hermaphrodite. ${ }^{8}$ In commentaries on Genesis, the hermaphrodite cropped up, as we shall see, because one of the 
interpretations which the scholastics rejected was the idea that the first human had been an androgynous being. Theologians and, especially, canonists were also interested in the hermaphrodite for more practical reasons, which reveal some of the social implications of sex difference. They asked how hermaphrodites must be baptized, whether they should be allowed to marry — and if so, with partners of which sex? - and whether they might be ordained as priests.

Despite the fact that medieval medicine and natural philosophy provided purely naturalistic explanations for the existence of hermaphrodites, Joan Cadden has argued that anatomically ambiguous individuals were, even in scientific texts, often seen as rebellious and disruptive in accordance with more widely held views in various sectors of medieval society. There was a general tendency, she suggests, "to reduce [hermaphrodites] to permutations of the conventional categories of masculine and feminine," which precluded any clear distinction between various forms of sexual ambiguity. While gender paradoxes could have a positive value in certain forms of religious language (such as the metaphor of Jesus as mother), "canonists reflecting on unusual anatomy or behavior in ordinary people sounded more hostile." 9

The discussions about the hermaphrodite in theology and canon law largely substantiate Joan Cadden's analysis, yet allow us to qualify it on some points. We shall see, in particular, that canonists generally discussed the problem of the hermaphrodite's access to the sacraments in morally neutral tones. Their approach to sexual identity was, moreover, highly pragmatic and made room for social criteria. Debates about the specific and limiting case of the hermaphrodite can, finally, be read as more generally indicative of the importance of sex difference and gender distinctions. Such a reading suggests that canon law, compared to other intellectual frameworks, was relatively egalitarian.

\section{The Creation of Sex Difference}

Genesis tells two different stories about the origin of sex difference. According to the first (Gen. I:27), God created man and woman as the crown on the six-days' work: "[He] created man in his own image, in the image of God created he him; male and female created he them." The second, most familiar, account (Gen. 2:2I-22) describes how God 
first fashioned man from the earth and then created paradise for him, as well as the animals, which he placed under his command. At Adam's request for a companion, God made him fall asleep and fashioned woman from his rib. After the Fall, she would be known as Eve.

The differences between these accounts had stimulated debates about the origin of sex difference since Antiquity, among both Christians and Jews. One of the solutions to the apparent contradictions of Genesis was the Jewish legend of Lilith. According to this tradition, Lilith, not Eve, was the first woman. Created from the earth, like Adam, Lilith proved rebellious and unfaithful, demanding total equality with her husband and eventually abandoning him for the company of demons. Faced with Adam's despair, God then created a second woman from his rib, in the hope that this would make her more faithful.

It would seem that medieval theologians discovered the story of Lilith only at the end of the twelfth century, probably through personal contacts with Jewish informants. ${ }^{\circ}$ Whatever the case, scholastics never took this particularly misogynous interpretation of Genesis very seriously and dismissed it, without much debate, as a frivolous Jewish fable. Despite his knowledge of Hebrew and his interest in Jewish exegesis, the Franciscan Nicholas of Lyra, author of a hugely influential commentary on the whole Bible, did not even mention Lilith. ${ }^{\text {II }}$

However, the fundamental idea behind Lilith's legend, i.e., that the manner in which God created man and woman reveals his social intentions and that woman's origin determines her relationship towards her husband, is, as Joan Cadden has pointed out as well, also a prominent feature of Christian exegesis. The position of medieval commentators is more moderate, but, as so often, not without ambiguities. ${ }^{12}$ Some claimed that God created woman from Adam's rib, and not from the earth, in order to stimulate his love for her. ${ }^{13}$ Others added that conjugal love is vital for the human race, since husband and wife must stay together all their lives, and that this is why among all living beings, only the human female is created from the male. ${ }^{I 4}$ By choosing to fashion woman from Adam's rib, rather than his head or his foot, God was taken to show, moreover, that woman should neither dominate her husband, nor be his servant, but, instead, a true companion. ${ }^{15}$ However, as many theologians pointed out, the manner of creation of woman also indicates 
that the relationship is not an equal one. Woman is created from the man, and not the opposite, so that she be under his authority ( $u t a b$ eo regatur) within marriage. Paul's statements that the man is the head of the woman (I Cor. II.3) and that the woman has been created for the man, and not the man for the woman (I Cor. II.8-9) helped to buttress this point. The story of creation thus served to affirm the natural submission (secundum conditionem naturae) of wife to husband. ${ }^{16}$

Whereas Lilith's legend doubles the creation of the first woman, another Jewish solution to the contradictions of Genesis doubles the body of the first human. ${ }^{17}$ According to this interpretation that was already signalled by Augustine, God had first created an androgynous double being (the first creation story), which he later cut in half to create man and woman (the second story). Apart from important philological arguments against this interpretation, which I shall not dwell on here, scholastics rejected it for moral and philosophical reasons not found in their Patristic models. ${ }^{18}$

In the IIgos, the Parisian theologian Peter the Chanter launched a strongly anti-homosexual reading that would be taken up by several later commentators. He argued that had the first human indeed been an hermaphrodite, God would seem to have given homosexuals a justification for having sex with a man instead of a woman, "as if men have both sexual organs." 19 The association between sexually ambiguous anatomy and behavior in itself was not new. Ancient animal lore, which had found its way into medieval bestiaries and encyclopedias, already presented some animals, such as the hare, the hyena, and the weasel as both homosexual and hermaphroditic (or as changing their sex regularly). ${ }^{20}$ Less frequently, it was claimed that some hermaphroditic animals, such as the hare, could self-reproduce. ${ }^{21}$

The author of On the Human Body cited these and similar animal legends explicitly, but confronted them with Aristotelian philosophy and zoology. His rejection of the hypothesis of an androgynous first human was based on the idea of the perfection of paradise and the order of nature. At first sight, the union of male and female in one individual, and the concomitant possibility of self-reproduction, might seem to exemplify the Aristotelian claim that nature favors simplicity, economy, and self-sufficiency. However, the author of On the Human 
Body doubted, like most scholastic philosophers, that hermaphrodites could self-reproduce. More important, he noted that nature, according to Aristotle, also respects other, more pressing, criteria of perfection, such as the separation of active (male) and passive (female) principles. As a mixture of male and female, the hermaphrodite incarnates disorder (confusio), which nature abhors, rather than the perfection she seeks. Worse, this physical condition allows for sex-role inversion, which, in humans, the noblest of all animals, is an abomination (abusio). God created woman "to avoid that the union of the sexes in one and the same person causes confusion, which both nature and the right judgement of reason flee." ${ }^{22}$ As mixtures of the active and the passive, male and female, and unable to control their sexual capacities, hermaphrodites violate the order of nature, which is understood both as a physical system and a moral norm.

The confrontation with Greek exegetical traditions led scholastics to make a more positive case in favor of sex difference and the creation of woman. Several Greek Church Fathers had presented sex difference as a result of sin and claimed that humanity, in its original state, had been not androgynous, but entirely asexual. This strongly neoplatonic reading, which goes back to Philo of Alexandria and Origen, is based on a radical distinction between body and soul and on the idea of creation as a progressive departure from the spiritual towards the inferior world of material bodies. In this view, the first creation story in Genesis had to be understood as the creation of the human soul, which is immaterial and asexual, while the second described its incorporation, leading to the appearance of sex difference. Gregory of Nyssa, followed by John Damascene, qualified sex difference more explicitly as a result of the Fall. Created after God's image, original human nature was incorporeal, eternal, and asexual; this is the existence humans will recover after the Resurrection. However, since God foresaw that, because of their sin, Adam and Eve would lose their immortality, he created beforehand the means for them to overcome death. According to Gregory of Nyssa, sex difference existed in paradise, but already deviated from the prototype of human nature in God's mind. Moreover, prelapsarian bodies were spiritual and pure in nature, allowing them to reproduce asexually, like angels. In this view, sexuality only became useful after the Fall. 
Augustine had already firmly rejected this view of creation. Even though he agreed that sex difference is not part of God's image in humanity, he held that it is all the same part and parcel of human nature created according to Divine will. Its goal is procreation, sanctified by marriage. For any other purpose, a male companion would, so Augustine stated, have been preferable. Had they not sinned, Adam and Eve would have had intercourse and would have procreated in paradise (albeit not to guarantee the survival of the human race, but to replace the fallen angels). Intercourse would, however, have been devoid of sin or shame, an act as neutral as a handshake. Augustine thus took position not only against Manicheism and extreme asceticism (by emphasizing both the sanctity of marriage and the natural character of generation and sexual difference), but also against Pelagianism (in defending the real consequences of the Fall).

The author of On the Human Body took up afresh this Augustinian justification of sex difference in the light of the new Aristotelian natural philosophy, while, at the same time, criticizing the famous Aristotelian description of woman as a "failed man" (mas occasionatus). For, if woman is, as suggested by Aristotle in On the Generation of Animals (II.3.737), an error of nature, how can she be present in paradise? The author of On the Human Body was not the first theologian to come up against Aristotle's expression. Thirty years earlier, William of Auvergne, master of theology at the University of Paris, and, from I228 on, bishop of that city, was one of the first readers of Michael Scot's Latin translation of Aristotle's zoology. ${ }^{23} \mathrm{He}$ cited Aristotle's qualification of womankind within a long justification of Christian marriage based, among other arguments, on the perfect complementarity of male and female in procreation. Even though women's role in generation is only passive and ancillary, both sexes are good and praiseworthy in themselves. From this perspective, calling woman a failed male is unacceptable (nec est audiendum Aristoteles) and even seems to imply a justification of homosexuality. ${ }^{24}$ If a man is allowed to have intercourse with an imperfect male, would it not follow that he may do the same with a perfect woman, i.e., a man?

At the time when William wrote his De sacramentis, Aristotle's books on natural philosophy had not yet become authorative; in Paris they were even still officially banned. This may explain William's highly 
selective use of Aristotle, adopting, without saying so, the Aristotelian theory of generation (which allowed him to qualify men and women as complementary, the male being active, the female passive), while also dismissing without qualms his definition of woman as a failed male, even though the latter is a direct corollary of the Aristotelian theory of generation.

The anonymous author of On the Human Body shows a more thorough understanding of what Aristotle had meant. He had called woman a mas occasionatus because, in his view, in every specific act of generation, nature aims for a boy. In this sense, the generation of girls is due to a defect of the natural powers and can be assimilated to the generation of a monster. However, Aristotle hastened to add, contrary to real monsters, women are necessary for the perpetuation of the species and thus have a final cause.

Even though the anonymous Franciscan accepted this analysis, he did not fail to realize that the Aristotelian justification of the female as a necessary error of nature led to problems when applied to the prelapsarian state, when humankind enjoyed immortality and perfect physiology. As shown by Peter Biller, scholastic theologians had, by i250, started to ask questions about the proportion of men and women in paradise had Adam and Eve not sinned. ${ }^{25}$ They argued that letting perfect nature follow its course, Adam and Eve would only have had boys (or at least far more boys than girls), skewing the sex ratio and jeopardizing future procreation. In order to conceive girls, Adam would have had to rein in his sperm by the force of his imagination, and thus by an act of the will. ${ }^{26}$

However, if the generation of girls only comes naturally after the Fall, in an already degenerated nature, one would seem to slip back into the error of the Greeks, who considered sex difference as a consequence of sin. At the time, refuting this old error may well have seemed urgent, because the Church saw itself confronted by the heresy of the Cathars, who rejected the body, sexuality, and the sacrament of marriage and were particularly wary about female physiology. ${ }^{27}$ The author of $O n$ the Human Body seems aware of this danger, because he stressed, citing Augustine and Julian of Toledo, that the female sex is not a sin, but a natural state (non est vitium sexus femineus, sed natura); part and parcel of the "Truth of human nature." After the Resurrection, our bodies will be 
perfect, and they will be male and female bodies. ${ }^{28}$ However, humankind will, then, no longer procreate. The glorious body has a sex, but it has no sexuality. ${ }^{29} \mathrm{~W}$ ith this appeal to the scholastic concept of the veritas bumanae naturae, the author of On the Human Body moved away not only from Aristotle's but also Augustine's purely utilitarian justification of sex difference, which valued woman only with respect to her role in generation. ${ }^{30}$ Sex difference appears here, rather, as an essential and intrinsic trait of one and the same human nature.

\section{The Hermaphrodite, the Sacraments, and the Construction of Gender}

Even though theologians barred the hermaphrodite from paradise, they recognized the existence of anatomically ambiguous individuals since the Fall. Consequently, theologians and, especially, canonists asked how the Church should treat hermaphrodites and, more specifically, whether, and under which circumstances, they could receive the sacraments of baptism, marriage, and ordination. As has been pointed out by Joan Cadden and others, medieval physicians and philosophers held that sex difference admitted of degree, while some medical models implied the existence of a perfect intermediary between man and woman, for example in linking sex determination to the place occupied by the seed in the uterus (left/right) and by assigning to the hermaphrodite a place in the middle. ${ }^{31}$ However, from the thirteenth century on, as Aristotle's influence made itself increasingly felt, it was usually claimed that one of the sexes necessarily dominated, although it might be difficult, in practice, to establish which. Canonists and theologians also tended to fit the hermaphrodite into a binary construct. Robert of Courson, a student of Peter the Chanter, backed up this legal reductionism with a reference to the opinion of the physicians. ${ }^{32}$ More commonly, canonists and theologians recognized the existence of a pure middle term, besides predominantly male and predominantly female hermaphrodites.

Interestingly, anatomy was, however, of relatively limited importance as a criterion for classification. When physical appearance did play a role, it was as much about beards, which can be seen without invasive examination, as about penises, breasts, or vaginas. Canonists seem to have viewed the sexual identity of hermaphrodites above all as a social reality. Peter 
the Chanter signalled that the Church allowed hermaphrodites to marry according to the sexual organ which procured the most pleasure. ${ }^{33} \mathrm{His}$ near contemporary, the great Bolognese canonist Huguccio, insisted not on sexual function, but on public behavior as indicative of the underlying real sex. If hermaphrodites prefer male activities and the company of males, the law will consider them accordingly. ${ }^{34}$ Even though gender is not a matter of pure choice, hermaphrodites can, according to this model, influence their assigned identity by their behavior. This approach to gender is all the more remarkable as in a similar context, that of the obstacles to marriage, examining the (male) genitalia is the principal proof to determine whether the marriage has been consummated or not, a condition of its validity. 35

The hermaphrodite is hardly a staple topic in medieval canon law and theology. Debates about the hermaphrodite's access to the sacraments are concentrated in a rather brief period of time, between the II7os and the early decades of the thirteenth century. The problem did find its way into a popular late medieval collection of questions related to nature and the human body. ${ }^{36}$ However, canonists and theologians seem, by then, to have lost interest themselves. The same is true, as suggested by Nicholas of Lyra's commentary on Genesis, of exegetes. Nicholas based his refutation of the idea of an androgynous first human being not on its sexual ambiguity, but on its doubleness, citing a pair of female siamese twins as an analogy. ${ }^{37}$

A comparison with medieval Muslim law provides another standard against which to evaluate the scholastic debates about the hermaphrodite. In Muslim law, the cases and contexts taken into consideration are much more diverse, ranging from rules for pilgrimage, prayer, ritual purity, the washing of a corpse before burial, the wearing of jewelry and silk clothing, to cases of libel and the rules for succession..$^{38}$ This greater richness may well reflect the more fundamental importance of gender distinctions in the societies of the Middle East. By comparison, medieval canon law tends to treat men and women equally, except in special cases like the priesthood. For instance, while Roman law (in which the hermaphrodite, revealingly, also plays a prominent role) refuses the testimony of a woman for the drawing up of a will, her testimony is valid in the ecclesiastical courts. 
For baptism, sex is of little importance, since males and females can receive the sacrament and since the sacramental formula is the same for both. Only the name of the child is sex-specific. Peter the Chanter laconically recommends the use of a male name when in doubt about the dominant sex; if necessary, its female variant may later be used for the sacrament of confirmation. The same rule applies to emergency baptisms during a difficult birth, when the sex of the child is still unknown. ${ }^{39}$ Despite the fact that the male name is clearly the default here, access to baptism itself is not at issue..$^{40}$ The same structural parallelism holds true for the sacrament of marriage. Both predominantly male and predominantly female hermaphrodites may marry a partner of the sex opposite to the hermaphrodite's own dominant sex.

By contrast, since women cannot be priests, only predominantly male hermaphrodites may be ordained. Canonists justified this solution by the principle in civil law that prohibits women and female hermaphrodites, but not male hermaphrodites, from testifying for the drawing up of a will (Huguccio assimilates the "pure" hermaphrodite legally to a woman, because it cannot be said that the male element dominates)..$^{41}$ In other contexts, canon law refuses even the ordination of predominantly male hermaphrodites, but this exclusion is based not on their sexual ambiguity but on their monstrosity, physical defects being, like illegitimacy or illiteracy, an obstacle to the priesthood..$^{2}$

Scholastic debates about Eve and the hermaphrodite would both seem to reflect, in their own way, the universalism of the Christian tradition, which downplays sexual or ethnic differences in order to celebrate the fundamental unity of humankind. In the medieval law of the Church, the hermaphrodite is a discrete presence, when compared to other law systems. Likewise, On the Human Body represents the culmination of the scholastics' efforts to comment on the creation of woman anthropologically; later debates lack the vivacity and urgency of this treatise. ${ }^{43}$ Of course, this does not mean that theologians and canonists were indifferent to sex difference, and even less that they viewed sexual ambiguity favorably. In commentaries on Genesis, medieval theologians based their justification of the creation of woman to a large extent on the rejection of physical conditions that compromised the binary division between the sexes. In the eyes of medieval theologians, hermaphrodites' supposed 
capacity for alternately adopting male and female roles in intercourse likened them to homosexuals and made them the object of condemnation and indignation. In On the Human Body, hermaphroditism appeared both as an error of and a vice against nature. That sex role inversion was indeed the central issue is confirmed by Nicholas of Lyra, who replaced the hermaphrodite by siamese twins. Monsters, he argued on Aristotelian lines, are "accidents" of nature and as such incompatible with the perfection of paradise. ${ }^{44}$ The order of nature does, however, not have a moral connotation here, and Nicholas's tone is perfectly neutral.

While theologians, in their commentaries on the creation, condemned hermaphrodites in extremely harsh terms, canonists tended to discuss their access to the sacraments in a remarkably neutral way, while defending a largely constructivist and pragmatic view of gender. However, the reversal of sexual roles in the case of remarriage shows the limits of this relative tolerance even here. According to Peter the Chanter, hermaphrodites had to adopt a gender and stick to it for the rest of their lives. If they had no clear preference, they had to remain celibate "in order to avoid any resemblance with the inversion of the sodomites, whom God abhors." 45 Peter the Chanter is, of course, not a canonist but a theologian, and it is surely significant that I have not found this precise position and wording, including the reference to sodomy, among the canonists themselves. However, according to the Glossa ordinaria, Huguccio dismissed the question of remarriage as "monstrous." 46

The possibility of sex role inversion was perceived as a danger to the order of nature, understood both as a physical system and a moral code. Women's undisputed place in this natural order was, as we have seen, not without ambiguities. While defending the female condition as part and parcel of the Truth of human nature, scholastic theologians underscored that her submission to her husband was just as natural. In fine, scholastic debates about Eve and the hermaphrodite confirm the extreme complexity and multilayeredness of medieval meanings of sex difference, so masterfully brought to light by Joan Cadden.

Université Paris Diderot-Paris 7 / Institut universitaire de France 


\section{@ END NOTES}

I. In her soon to be completed new book on views about male homosexuality in medieval commentaries on and manuscripts of Aristotle's Problemata, this sensitivity to the literary and material form of medieval debates is even more marked. Parts of the book have already been published as separate articles: "Nothing Natural is Shameful: Vestiges of a Debate about Sex and Science in a Group of Late-Medieval Manuscripts," Speculum 76 (200I): 66-89; "Sciences/Silences: the Natures and Languages of 'Sodomy' in Peter of Abano's Problemata Commentary," in Constructing Medieval Sexuality, ed. Karma Lochrie, Peggy McCracken, and James A. Schultz (Minneapolis: University of Minnesota Press, 1998), 40-57; "Preliminary Observations on the Place of the Problemata in Medieval Learning," in Aristotle's Problemata in Different Times and Tongues, ed. Pieter De Leemans and Michèle Goyens, Mediaevalia Lovaniensia; ser. I, st. 39 (Leuven: Leuven University Press, 2006), I-20.

2. Joan Cadden, Meanings of Sex Difference in the Middle Ages: Medicine, Science and Culture (Cambridge : Cambridge University Press, 1993), 276-77.

3. Caroline W. Bynum, The Resurrection of the Body in Western Christianity, 200-I336 (New York: Columbia University Press, 1995); Peter Biller, "Introduction: John of Naples, Quodlibets and Medieval Theological Concern with the Body," in Medieval Theology and the Natural Body, ed. Peter Biller and A. J. Minnis (Woodbridge: York Medieval Press, 1997), 3-I2; Idem, The Measure of Multitude: Population in Medieval Thought (Oxford: Oxford University Press, 200o); Alain Boureau, Théologie, science et censure au XIII siècle. Le cas de Jean Peckbam (Paris: Les Belles Lettres, 1999); Joseph Ziegler, "Ut dicunt medici'. Medical Knowledge and Theological Debate in the Second Half of the Thirteenth Century," Bulletin for the History of Medicine 73 (1999): 208-37; Idem, "Medicine and Immortality in Terrestrial Paradise," in Religion and Medicine in the Middle Ages, ed. Peter Biller and Joseph Ziegler (Woodbridge: York Medieval Press, 200I), 20I-42. See also Maaike van der Lugt, Le ver, le démon et la vierge. Les théories médiévales de la génération extraordinaire (Paris: Les Belles Lettres, 2004) and Chiara Crisciani, "Aspetti del dibattito sull'Umido radicale nella cultura del tardo Medioevo (secoli XIII-XV)," in Actes de la II trobada internacional d'estudis sobre Arnau de Vilanova, ed. Josep Perarnau (Barcelona: Institut d'estudis catalans, 2005), 333-80.

4. This is the case, for instance, for the views on the role of the male and the female in reproduction that are expressed in the debate about Mary's 
contribution to the conception of Christ. Cf. Van der Lugt, Le ver, le démon et la vierge.

5. I have studied this theme in more detail in "Pourquoi Dieu a-t-Il crée la femme? Différence sexuelle et théologie médiévale," in Ève et Pandora. La création de la femme, ed. Jean-Claude Schmitt (Paris: Gallimard, 200I), 89-II3 (notes on 262-67).

6. Cadden, Meanings of Sex Difference, I89-90.

7. De corpore bumano, 'De corpore muliebri' = Alexandri de Hales Summa theologica, II, inq. iv, tract. ii, sect. ii, q. ii, 463-68 (Quaracchi: Collegium S. Bonaventurae, 1928), II, 610-30. Thomas Aquinas, Summa theologiae, ra, q. 92, art. I; Ia, q. 99, art. 2.

8. On this theme, see also my article "L'humanité des monstres et leur accès aux sacrements dans la pensée médiévale," in Monstre et imaginaire social. Approches historiques, ed. Anna Caiozzo and Anne-Emmanuelle Demartini (Paris: Créaphis, 2008), 135-62, (with Latin notes on http:// halshs.archives-ouvertes.fr/halshs-0oI75497/fr/).

9. Cadden, Meanings of Sex Difference, 2OI-2, 209, 2I2, 214.

Io. Albertus Magnus, who tells the story of Lilith in more detail than his predecessors, may well have learned about it through his fellow friars at the convent of Saint-Jacques since the Dominican order counted, at the time, many Jewish converts. For more details, see Van der Lugt, "Pourquoi Dieu," 93-94.

II. Ibid., 92-95.

I2. Cadden, Meanings of Sex Difference, 193.

13. For example Andrew of Saint-Victor, Expositionem super Heptateuchum, ad Gen I:27 et 2:22, ed. Charles Lohr and Rainer Berndt, Corpus Christianorum Continuatio Mediaevalis 53 (1986), 21, 33; Thomas Aquinas, Summa theologiae, ra, q. 92, art. 2.

I4. Thomas Aquinas, ra, q. 92, art. 2; Nicholas of Lyra, Postillae, ad Gen I:27 (ed. Douai, I627, I, c. 34). The Glossa ordinaria (ad Gen I:27) explains the specificity of the creation of humankind by its unity rather than by the indissolubility of marriage.

15. For example, Hugh of Saint-Victor, De sacramentis, I, 6, 35 ( $P L$ 176, c. 284); Peter Lombard, Sententiae, II, dist. I8, 2, (Magistri Petri Lombardi Sententiae in IV libris distinctae [Grottaferrata, 197I-8I], 2 vols, I : 416-17); Nicholas of Tournai, In Pentateucbum, ad Gen 2:2I (Paris, Bibliothèque Nationale de France, MS lat. 15572, fol. II4v); Hugh of Saint-Cher, Postillae, ad Gen 2:2I (ed. Cologne, I62I, 8 vols, I, fol. sv); Albertus Magnus, Summa 
de creaturis, II, q. 75, ad 4 (Opera omnia, ed. Auguste Borgnet, 35, 627); Thomas Aquinas, Summa theologiae, ra, q. 92, art. 3.

I6. Glossa ordinaria, ad I Cor II (ed. Strasbourg, I480, without folio numbering). This interpretation is taken up in several doctrinal summae, for instance Alexandri de Hales Summa theologica, II, pars I, inq. iii, tract. iii, q. ii, art. I, 315, ad 5 (ed. cit., II, 379): "sicut originem sumpsit ex viro, ita debeat esse viro subdita secundum conditionem naturae," Thomas Aquinas, Summa theologiae, ia, q. 92, art. 2.

17. However, before Nicolas of Lyra in the early fourteenth century, commentators knew the tradition only indirectly, through Augustine, who did not signal its Jewish origin. Cf. Van der Lugt, "Pourquoi Dieu," 96.

I8. Ibid., 96-97.

19. Peter the Chanter, Glossae super Genesim, ad Gen I:27 (ed. A. Sylwan, Göteborg, 1992, 40-4I): "Masculum et feminam creavit eos. Sic construe ut locum habeat ratio, quasi dicat 'Deus creavit hominem', non solum unum hominem, sed duos, nec in uno tantum sexu, sed in utroque, quia masculum et feminam creavit eos, non androgynos, id est non hermaphroditos qui viri et mulieris simul habent instrumentum. Ergo pluraliter dicit, ne putaret homo sodomita posse abuti homine loco mulieris, quasi homo utrumque haberet instrumentum."

20. J. Boswell, Christianity, Social Tolerance and Homosexuality. Gay People in Western Europe from the Beginnings of the Christian Era to the Fourteenth Century (Chicago: University of Chicago Press, 1980), 137-43, $305-8$.

21. Pliny, Historia naturalis, 8.81.218. However, medieval bestiaries and encyclopedias generally do not report this idea, but merely note the possibility for the same individual to adopt the male or the female role. For more details, see Van der Lugt, Le ver, le démon et la vierge, 93-94.

22. De corpore bumano, De corpore muliebri, caput $\mathrm{I}=$ Alexandri de Hales Summa theologica, II, inq. iv, tract. ii, sect. ii, q. ii, 463, 5, solutio, and ad 5 (Quaracchi: Collegium S. Bonaventurae, I928), II : 6II-I4). Solutio (ibid., 612-I3): "Natura desiderat perfectionem et refugit confusionem, et ideo debuit homo fieri taliter ut esset in eo perfectio ad actum propagandi, et ita in primaria hominis conditione debuit fieri agens et patiens, et haec inconfusa. Et hinc est quod mulier formata fuit a viro distincta, ne, si pluralitas sexuum in unam personam concurreret, confusionem faceret, quam refugit natura et rectum rationis iudicium, sicut videmus circa hermaphroditum." 
23. Aristotle, De generatione animalium, II.3.737 = De animalibus, 16 (Aristotle, De animalibus. Michael Scot's Arabic-Latin Translation, Books $X V$-XIX: Generation of animals, ed. Aafke van Oppenraaij [Leiden: Brill, 1992]), 76 .

24. William of Auvergne, De sacramentis, 'De sacramento matrimonii,' cap. 3 (Opera omnia, Paris/ Orléans, 1674, I : p. 515b-16a): "Nec est audiendus Aristoteles, qui dicit in libro suo de naturis animalium, quod foemina est mas imperfectus; eodem modo necesse habet dicere quod mas est foemina perfecta, que sententia sapit haeresim sodomicam (!). Nos autem dicimus quod masculinitas vis generativa est activa, ut supra diximus, et foemininitas vis generativa passiva, et utraque est bona et laudanda dispositio, atque perfectio in suo subjecto, et foemininitas est adjutrix, sive adjutorium masculinitatis. Quare ergo ex mare et foemina, quasi ex duobus ramis consistit arbor ista pretiosissima, et vis generativa, seu fructificativa hujus arboris erit et consistet ex duabus viribus dictis." See also ibid., cap. I (ed. cit., $512 \mathrm{~b}-513 \mathrm{a})$.

25. Biller, The Measure of Multitude, 89-IIо. The first developed discussion about this theme is found in Bonaventure's commentary on the Sentences (1250-52). However, the thought of sex ratio emerges sporadically (but not with respect to paradise) from the second quarter of the thirteenth century on. William of Auvergne's rejection of the Aristotelian qualification of woman is part of his argument in favor of equal numbers of men and women. Biller links the birth of the notion of sex ratio with the reception of new medical and philosophical material about sex determination, and, more tentatively, with the observation of differences in the number of religious men and women and in lay society (IO4-IO).

26. Bonaventure, In II Sententiarum, ad dist. 20, art. I, q. 6 (Opera theologica selecta. editio minor, ed. Leonardus M. Bello [Quaracchi: Collegium S. Bonaventurae, I938], II: 50I): "Sed tempore naturae institutae, in qua corpus subiectum erat animae, principalis ratio sumitur generationis maris et feminae a parte virtutis animalis moventis et imaginantis. Cum enim vir intenderet et vellet generare virum, tunc vigoraretur virtus naturalis eius in agendo et esset semen maioris virtutis et generaretur sexus vigorosus sive masculus; quando vero vellet et imaginaretur generare sexum femineum, tunc minus forti impressione ageret in naturam inferiorem corporalem, et tunc semen esset minus forte et generaretur sexus femineus: et ideo in tempore naturae institutae generatio maris et feminae subesset voluntati rationali." To be sure, the generation of males is also presented as subject to the will. However, Bonaventure admits that on the purely physical level, prelapsarian 
nature favors the generation of boys. This argumentation is found almost verbatim in De coniuncto bumano, another treatise appended to Alexander's Summa (II, inq. iv, tract. iii, q. ii, 504, ed. cit., 724-25).

27. Cf. Peter Biller, "Cathars and Material Women," in Medieval Theology and the Natural Body, 6I-I08; K. Utz Tremp, "Parmi les hérétiques. La Vierge Marie dans le registre d'inquisition de l'évêque Jacques Fournier de Pamiers (1317-I326)," in Marie, le culte de la Vierge dans la société occidentale, ed. Dominique Iogna-Prat, Eric Palazzo, and Daniel Russo (Paris, Beauchesne, 1996), 533-60, 546.

28. De corpore humano = Alexandri de Hales Summa Theologica, II, inq. iv, tract. ii, sect. ii, q. ii, 463 ad 7 (ed. cit., 6r5): “. . . nec verbum eius [i.e. Aristotle's qualification of woman as a failed male] veritatem habet quantum ad statum primae conditionis: natura enim muliebris aeque pertinet ad veritatem naturae humanae sicut natura virilis, sicut probat Iulianus Toletanus, in libro qui dicitur Prognostica futuri saeculi, libro 3, cap. 23, et introducit verbum Augustini dicentis: 'non est vitium sexus femineus, sed natura'; corporibus enim illis in futuro vitia detrahentur et natura salvabitur.' Quod nullo modo esset, nisi differentia sexus pertineret ad naturam."

29. And one sex only. In the I230s, the Dominican theologian Hugh of Saint-Cher asserted that the hermaphrodite will rise in a body of the sex "which nature would have given him had she not been diverted from her goal" (in illo sexu quem nature ei daret si non impediretur). Commentarius in Sententias, IV.44 (Paris, Bibliothèque nationale de France, MS lat. 3073, fol. I59ra). All other imperfections, such as missing limbs, will also be corrected. On these questions, see Bynum, The Resurrection of the Body.

30. On this concept, see Philip Lyndon Reynolds, Food and the Body: Some Peculiar Questions in High Medieval Theology (Leiden: Brill, 1999), chap.2; Alain Boureau, "Hérédité, erreurs et vérité de la nature humaine (XIIe-XIIIe siècles)," in L’hérédité entre Moyen Âge et Epoque moderne. Perspectives historiques, ed. Maaike van der Lugt and Charles de Miramon (Florence: Sismel, 2008), 67-82.

3I. Cadden, Meanings of Sex Difference, 2II-I2.

32. Robert of Courson, Summa, De hermafroditis : “... ut tradunt physici, non potest contingere quod duo sexus in hermafrodito equaliter vigeant, immo oportet quod semper unus obtineat privilegium" (Paris, Bibliothèque nationale de France, MS lat. 3258, fol. 2oova).

33. Peter the Chanter, Verbum abbreviatum, 138 'de vitio sodomitico' (PL 205, 334): "Masculum et feminam creavit eos quasi: non erit consortium 
viri ad virum, vel mulieris ad mulierem, sed tantum viri ad mulierem, et econtrario. Unde Ecclesia homini androgyno, id est habenti instrumentum utriusque sexus, aptum scilicet ad agendum et patiendum, instrumento, quo magis calescit, quove magis est infirmus, permittit uti. Si magis calescit, ut vir, permittunt eum ducere; si vero magis mollescat, ut (ed. et) mulier, permittunt ei nubere. Si autem in illo instrumento defecerit, nunquam concederetur ei usus reliqui instrumenti, sed perpetuo continebit, propter vestigia alternitatis vitii sodomitici, quod a Deo detestatur." Peter the Chanter also discusses the problem of the marriage of the hermaphrodite in his Summa de sacramentis et animae consiliis, III, 2a, cap. 17, par. 254 (ed. J.-A. Dugauquier, Analecta mediaevalia namurcensia, XVI, 259). According to the Summa 'Omnes homines' (ed. Paris I500, without folio numbering), hermaphrodites must swear which organ is most functional in order to determine whether the court will consider them as men or women: "Queritur utrum debet stare in iudicio loco viri vel mulieris. Responditur secundum viam iuris quod primo debet iurare antequam admittatur ad iudicium quo membro posset uti et secundum hoc est admittendus iuxta usum et potentiam illius membri."

34. Huguccio, C. IV, q. 2 et 3, c. 3, par. 22, ad v. sexus incalescentis (Paris, Bibliothèque nationale de France, MS lat. 15396, fol. 136va): "ostendit quia si magis incalescat in virum quam in femina, id est in opera virilia quam feminea, quia si sexus virilis in eo prevalet adhibetur etiam in testimonio si femineus non admittitur in testamento, quia femina in testamento testis esse non poset (!)... s si quidem habet barbam et semper vult exercere virilia et non feminea et semper vult conversari cum viris et non cum feminis, signum est quod virilis sexus in eo prevalet et tunc potest esse testis ubi mulier non admittitur, scilicet in testamento et ultimis (ms. multimis) volumptatibus, tunc etiam ordinari potest. Si vero caret barba et semper vult esse cum feminis et exercere feminea opera, iudicium est quod feminini (!) sexus in eo prevalet et tunc non admittitur ad testimonium ubi femina non admittatur, scilicet in testamento, sed nec tunc ordinari potest, quia femina ordinem non recipit. Preterea ad talem discretionem multum valet inspectio genitalium, quid si illi duo sexus equales per omnia inveniuntur in eo credo quod debeat iudicari de eo tamquam femineus sexus in eo prevaleret quia verum est virilem sexum in eo non prevalere."

35. See the debate around X, 4, I5, De frigidis et maleficiatis, et impotentia coeundi (Corpus iuris canonici, ed. Emil Friedberg [Leipzig, I879]), II, c. 704-708).

36. In medieval manuscripts and early prints, the text is presented as a collection of Aristotle's problems (e.g. in the I500 Paris edition I have used). 
Scholars usually identify the collection by its opening words as the Summa 'Omnes homines.'

37. Cf. Van der Lugt, "Pourquoi Dieu," 97-98, 100. At the turn of the thirteenth and the fourteenth century, an important period for anthropological thinking among theologians, there is a small but significant vogue for questions about siamese twins. Nicholas of Lyra's choice to replace the hermaphrodite by siamese twins would seem to reflect these developments in theology. Like other limiting cases such as the embryo or the corpse, siamese twins served as models to define the complex relationship between soul and body, form and matter. See Van der Lugt, "L'humanité des monstres."

38. Cf. Hocine Benkheira, "Homme ou femme? Les juristes musulmans face à l'hermaphrodisme," in Monstre et imaginaire social, 163-86.

39. Peter the Chanter, Summa de sacramentis et anima consiliis, III, 2a, cap. xvii (ed. cit., 259). Emergency baptism during childbirth is possible as soon as the head, or another part of the child's body can be seen.

40. The author of the Summa 'Omnes bomines' bases the preference for a male name on the supposed natural superiority of the male, an explanation typical of the misogynous tendencies of the collection: “... responditur quod nomine viri. Ratio est quia nomina imponuntur ad placitum et secundum nomen dignius debet baptizari, quia omnis vir dignior est muliere, quia omne agens prestantius est suo passo, ut dicit Aristoteles in tercio de anima."

41. Digest, 22.5.15: "Paulus.... Hermaphroditus an ad testamentum adhiberi possit, qualitas sexus incalescentis ostendit." Gratian, Decretum, C. IV, q. 2 et 3, c. 3, par. 22 (Corpus iuris canonici [Leipzig, I879], I, c. 540). Huguccio, C. IV, q. 2 et 3, c. 3, par. 22, ad v. sexus incalescentis (see note 35 above).

42. Huguccio, C. XXVII, q. I, c. 23 ad v. ordinari: "Item ermafroditus, si ergo magis calet in femina quam in virum non recipit ordinem. Si e contrario recipere potest sed non debet ordinari propter deformitatem et monstruositatem" (Paris, Bibliothèque nationale de France, MS lat.I5396, fol. 6Irb). Laurentius of Spain, C. XXVII, q. I, c. 23, ad v. diaconissa: “. . . hermafroditum autem dico non promovendum propter populi scandalum licet in eo plus incalescat sexus virilis et ad alia virilia admittatur ut IIII q. III" (Città del Vaticano, BAV, MS Vat. Reg. lat. 977, fol. 22ov margin). Copied by Guy of Baysio, Rosarium, C. XXVII, q. I (ed. cit., fol. 335v). Also in the penitentials, for instance, Robert of Flamborough, Liber poenitentialis (I208-I2I3), III, 2, 76 De sexu (Robert of Flamborough, canon-penitentiary of Saint-Victor at Paris. Liber poenitentialis. A Critical Edition with Introduction and Notes, ed. J. J. 
Francis Firth [Toronto: Pontifical Press, I97I], IOI). For more details, see Van der Lugt, "L’humanité des monstres."

43. Van der Lugt, "Pourquoi Dieu," II2.

44. Ibid., 97-98, 100.

45. Peter the Chanter, cf. note 34 above. The Summa 'Omnes bomines' reports this position as well.

46. Glossa ordinaria, C. IV, q. 2 et 3, canon 3, par. 22 (ed. Lyons, I57I, c. 713): "Quaesitum fuit utrum hermaphroditus, idest qui habet sexum maris et feminae, possit esse testis in testamento ?... Sed quid si in omnibus est parilitas? Item numquid talis potest ordinari ? Item an contrahet cum viro, an cum muliere, et si prius cum viro contraxit, an possit eo mortuo cum muliere contrahere? Io<hannes Teutonicus $>$. Sed certe in omnibus his respici debet sexus qui magis incalescit. De monstro possunt fieri monstruosae quaestiones. Hug<uccio>." Huguccio's remark admittedly also refers to ordination, and possibly testifying, but the fact that mariage and remariage appear as the last item, and are described in more detail suggests that this was, indeed, the case that provoked Huguccio's remark. 